Canadian University Music Review

Revue de musique des universités canadiennes

\title{
An Interview with Rob Walser in Toronto
}

\section{Rob Walser, Teresa Magdanz et Simon Wood}

Volume 21, numéro 2, 2001

URI : https://id.erudit.org/iderudit/1014481ar

DOI : https://doi.org/10.7202/1014481ar

Aller au sommaire du numéro

Éditeur(s)

Canadian University Music Society / Société de musique des universités canadiennes

ISSN

0710-0353 (imprimé)

2291-2436 (numérique)

Découvrir la revue

Citer ce document

Walser, R., Magdanz, T. \& Wood, S. (2001). An Interview with Rob Walser in Toronto. Canadian University Music Review / Revue de musique des universités canadiennes, 21(2), 1-11. https://doi.org/10.7202/1014481ar
Résumé de l'article

À la fin de l'automne 2000, Toronto a été l'hôte d'un congrès international d'envergure qui a rassemblé des milliers de chercheurs en musique. À cette occasion, Teresa Magdanz et Simon Wood ont tenu une séance privée avec Robert Walser, professeur de musicologie à UCLA; ils ont débattu de nombreuses questions se rapportant à l'étude des musiques populaires, dont plusieurs avaient été soulevées lors du congrès. Les interviewers explorent la trajectoire des travaux de Walser, sa pensée sur les relations qu'entretiennent le savoir musical et l'interprétation, de même que ses réflexions sur la musique populaire et l'institution, dont les implications dépassent l'étude des musiques populaires et mettent en question la portée et la pratique du savoir musicologique.
All Rights Reserved (C Canadian University Music Society / Société de musique des universités canadiennes, 2002
Ce document est protégé par la loi sur le droit d'auteur. L'utilisation des services d'Érudit (y compris la reproduction) est assujettie à sa politique d'utilisation que vous pouvez consulter en ligne.

https://apropos.erudit.org/fr/usagers/politique-dutilisation/ 


\title{
COLLOQUY/DÉBAT: AN INTERVIEW WITH ROB WALSER IN TORONTO
}

\author{
Teresa Magdanz and Simon Wood (Interviewers), Rob Walser
}

In late autumn of 2000 , thousands of music scholars gathered at the international mega-conference in Toronto for five momentous days to argue, breathe, sleep, and talk music. Finding much of interest at the panel sessions, lectures, and round-tables, Teresa Magdanz and Simon Wood nonetheless craved some one-on-one discussion. Immediately following the conference they met privately with Robert Walser, Professor of Musicology at UCLA, to discuss a number of questions pertinent to popular music studies, many of which were raised at the conference. In their interview they explored the trajectory of his work, his thoughts on the relationship between music scholarship and performance, and his reflections on popular music and the academy, the implications of which extend beyond popular music studies to challenge the broader scope and practice of musicological scholarship.

Teresa Magdanz: Obviously, none of us has a chance to do it all over again, but if you did, would you be in academia, or would you be making music somewhere?

Rob Walser: I'm pretty happy with the way things have turned out. There was a time in the early $80 \mathrm{~s}$ when I thought I wanted to be an orchestral trumpet player, and I came within a hair's breadth of doing that. I came in second for the principal trumpet job with the Oklahoma Symphony, playing a week of subscription concerts with them as part of the final round. But I had already started to realize that orchestral trumpet playing is very un-free in a lot of ways-very restrictive. You don't have much control over interpretation; the conductor has all that authority. What you have is a kind of oral tradition of, i.e., you play it like that because that's the way your teacher played it, and that's the way his teacher played it. And it was around that time that I discovered musicology, not just music history courses which I had been forced to take, and mostly hated, but I started taking courses in the humanities department. Then I ran into Susan [McClary] and she turned me on to a different kind of music history where you could actually use your brain in a creative way and draw upon the valuable experience you get as a performer-that experience wasn't irrelevant, or opposed to scholarship-it was enabling. And I realize that most of what I've written over the last fifteen years has had some kind of connection to some kind of playing I've done at some point.

Simon Wood: Speaking of playing, I knew from your book Running With the Devil that you had a lot of experience as a player, both on guitar and trumpet. How important is it for us to try and keep playing at some level, when as 
musicologists we're frequently pushed away from our instruments due to time constraints? Does playing bring something to your work as a musicologist?

RW: I wouldn't say that it's the only way-that everybody should be doing this and not other things-but it's very valuable for me. There's that quote from Barbara Browning where she says, "a lot of what I know about samba I learned with my body first, and only later became able to bring into words." I learn things that way too. You don't always know what you are learning or why. There was a summer when Susan was playing French harpsichord music-just playing all summer. She didn't really know what she was learning or why. But it was a process of trying to figure out how these pieces really went-what made them tick. The conventional wisdom had been that they didn't really work, that they were just bad imitations of other things. It was just months of playing and not knowing or not being able to talk about what was being learned. I think that's been the case, and I'm trying to push that now with the trumpet stuff. I gave an Armstrong graduate seminar last spring, and that got me thinking in "Armstrong" ways and trying to play in Armstrong's style. It really dramatized some things for me, and so over the summer I've been trying to do a lot of Clifford Brown, which is a whole different kind of virtuosity. I've been working for months just to play a little snippet from Brown's recording of "Cherokee."

TM: I was just reading your article on the problematic interpretations jazz critics have traditionally made of Miles Davis' playing in the anthology Keeping Score: Music, Disciplinarity, Culture. That collection has been important for me in terms of rethinking various musical analytics, as well as the role of aesthetics in music-making. I' $m$ wondering if popular music or jazz studies can help us to rethink or valorize experience. Can we create a musical analysis that recognizes different types of experience and listening? It seems to me that was what Keeping Score was working towards.

RW: Yes, I think that's one thing that clearly comes out of bringing popular music studies more into musicology. What constitutes a text for analysis changes: we move either to a recording or a performance as the thing that we are trying to analyze. Scores are after the fact, if they exist at all. And in a way you can make the argument that when we are looking at scores from the past, we are looking at the textualization of a practice. We haven't tended to look at scores that way; the score is the work, the analytic object.

TM: Which assumes all experience to be one and the same.

RW: Right, because when things are textualized, they are made to look more the same. They are all reducible to a piece of paper with some kind of configuration of black ink on it.

TM: Coming back to the Miles Davis article once again, and the power of improvisation, much of what you critique is the way that critics have tended to make a simplistic homology between culture and freedom in the US of the 1950 s, using this to explain "freedom" in jazz. As you've stated, this really misses the boat on cultural complexity and obscures the ugly fact of racism. A further notion you talk about is that the individual freedom all comes together 
with players improvising, and that is how jazz is about freedom and individuality.

RW: There is something else about the emphasis on freedom and individuality that is important in jazz: people from whatever background, whatever position in society, are able, in performance, to be powerful, capable, masterful, and virtuosic. That's a tremendous feeling. That's a feeling that some people may get only when playing, and they're not allowed to have it in any other sphere of their lives. And yet that emphasis on freedom and individuality, I think, got into place because of cold-war priorities. What is pushed out of the way is cooperation and community. There is just as much to talk about in jazz that way because a jazz group is utterly interdependent-that's cooperation. In my book Keeping Time I have some press accounts of the 50s from the state department. They use the word "individuality" all the time in these articles, and it calls away from the communal aspects and how individuals are enabled by communities to have those experiences of individual freedom.

SW: Speaking of performance and experience, what are your thoughts on the idea of listening as a performative concept? I' $m$ very taken with Christopher Small and Charles Keil, authors you've referenced a few times.

RW: There is also a nice piece by my colleague Elisabeth Le Guin in Repercussions called "Uneasy Listening," about "easy listening" and what it means to listen like that. I find Chris Small's work really wonderful, and I tend to side with him on the idea that when we are listening we are also "musicking." What he means by that is that we are caught up in relationships-which he sees as the point of music - as defining, creating, celebrating, exploring, affirming, certain relationships among selves, and among people. We come to music like we come to any other activity: we come as people with values, with anxieties.

TM: With physical experience.

SW: And how do we get at those kinds of experiences, especially those of us who come from the logical, formalist zones of musicology?

RW: It's hard, because a lot of the accepted criteria of what counts as scholarly evidence pushes [the experience of musicking] out of the way.

SW: Because you're resorting to personal interviews-the experiences of people who haven't read all the appropriate authors.

RW: Yes, and I could be criticized for, "OK, so you can sort-of play like Armstrong, and you can sort-of play like Clifford Brown, but is that really evidence or is that just showing off?" And yet, there is a way in which I think working through to the point of being able to do that is an important kind of credibility for speaking about that music. The alternative is that we have people who don't know about something claiming objectivity about it, and expertise as a result of remoteness from it. At the same time I'm sensitive to the idea that it is easy to overdo the imaginary identification. These different people, Davis, Armstrong, and Clifford Brown were from very different generations; very different backgrounds, southern vs. Midwestern; the experience of a black man 
in a racist society in that part of the century vs. now. There are all these things that are different, and yet, there is this tremendous connection I think I can make through playing that is real and central, and was such a central part of their lives. I think it's a good starting place. And there's the Miles Davis piece, but I haven't yet written about the others. I'm sort of groping towards how to really express this in a way that will be useful to others, and not just other scholars. When I wrote Running With The Devil I was thinking that it would be great if I could write this so that metal fans could read it. And then I realized part way through that you can't address everybody at the same time. Dave Marsh, the rock critic, told me after he read the book that it would be great if I could do a different edition of it, take out some of the theory, you know, more pictures, less Bakhtin. And his reason was, first, he thought I could make a lot of money, and, second, he thought that it was politically important, that it would be empowering to many fans who were told that their culture sucks, and they, thus, are worthless. To be able to argue that and to talk about their culture in sophisticated ways could be important. I never did that. Writing is dialogic: you always have in mind someone or some people with whom you have to feel you are in conversation.

TM: And you have to commit yourself to that audience or group.

RW: Yes, and I can feel comfortable with that, influencing other scholars who influence other scholars, who teach thousands and thousands of students.

TM: We wanted to talk about that, about influencing other scholars and how you view the results. With respect to Running With The Devil, which has been out for the better part of a decade now, and maybe some of your earlier work, what are some of the promising connections that you have gotten purchase out of, or where have people picked up on your work?

RW: Susan Fast's book [In the Houses of the Holy: Led Zeppelin and the Power of Rock Music] is really gratifying to me because she does just what you hope people will do, which is take what you did, find some useful things in it, and then do something else that's worth doing. This will be the first real scholarly book on a single rock band. She approaches it from a number of different angles and picks up on some of the gender stuff that I did. [In Running With The Devil] I'm talking about thousands of bands, really a whole set of genres. She's focusing on one band so she can go into much more detail. But she's also extended some lines of thought which I only sketched, so that's really wonderful. Apart from that, there hasn't been as much as I'd like. Some students of mine are doing really interesting things. I'm really proud of David Ake who was my first Ph.D. advisee-he graduated a couple of years ago. His book will be coming out from California on jazz. It's his book, but it's not the book he would have written if he hadn't come in contact with me-we talked, and played together and argued about things - so that's very rewarding.

SW: Looking back on Running With The Devil, are there things that you still really like about it, or things that you would change if you could?

RW: It may sound immodest, although I guess it's a self-criticism too that I can't remember what I wrote, but every time I look back at it, I think, "wow, 
that's interesting [all laugh]." I wish I'd thought of that." There are some nice turns of phrase here and there, like "masculinity passed as a bad cheque." The things I like about the book are not the things that I made up but the things that I discovered were out there, like the way gender was being negotiated in different ways by different subdivisions of the metal scene. Or the selective appropriation of some classical music and adaptation of it, which was not the same as Gunther Schuler saying, "Gee, this [jazz] music is good because it's just like classical music." These people out there have just done this amazing appropriation and adaptation. What does it mean that some of the least prestigious musicians have taken some of the most prestigious stuff and made something new out of it? That was a digression [all laugh].

SW: Actually, I was always curious about your use of the term "heavy metal." It seems to me that a lot of the bands you covered would tend to be described as rock or hard rock by their fans.

RW: Yes, but if you look at fan magazines from the late 80s, which is when I was looking at them, I was taking the kind of definition that they were using. They wanted to be inclusive so that if you see your favorite band listed on the cover, you would buy the magazine. But they can't be too inclusive or they lose their credibility as metal magazines. So, there's that. And then, instead of saying, "here's my definition of heavy metal" and then, "here's how I'm going to proceed to study it," I foreground the processes of contestation and multiple definitions and so on. But I took [heavy metal] as the overall definition that could be used at that time to talk about people from Poison to Metallica. There were some fans who liked both bands. There were other fans, of course, who liked one or the other and despised the other side. In the late 80s you could go into a large record store and there would be a heavy metal section, separate from the rock section. That also defined the "canon" that made sense at the time. You would find Poison in there, and Bon Jovi, as well as AC/DC and Van Halen, Judas Priest, and Metallica. So there was a sense that part of the pleasure of arguing about what counts is that it takes place within a general framework. No one is going to argue whether Elton John is heavy metal, but there's a sense that here is a possible set of things that could be called heavy metal. And there is also the fact that at that time, heavy metal was a very prestigious term. People wanted to claim that term for the music that they liked, which has not always been the case. If fact, it became not the case. After Nirvana, the term "heavy metal" lost much of its prestige. You have bands who are doing a lot of the same things [as heavy metal bands] but didn't call themselves metal. There was nothing in it for them.

TM: Your detour from metal to jazz interests me for another reason. I guess I've always been wary of jazz studies or jazz, because I can't think of more than one or two women who have contributed to jazz scholarship. And as someone who played in stage band in high school, hung out at several jazz clubs on the West coast and listened almost exclusively to jazz radio, I remember it being such a masculinist world. For a number of years I've listened to guitarists Mike Stern, John Schofield, and Pat Metheny, and when I go to their gigs, I feel really 
marginal. Jazz, like any other musical/cultural phenomenon, is a complex gender site, but it's rarely written about in that way.

RW: I don't think I really switched from metal to jazz. The book and the Miles Davis article came out in the same year, but the book got more attention. So these have always been things that I have been thinking about. I deliberately did not want to do a second book on rock and just become known as "metal-boy" [all laugh]. But your question is a really good one and I think the point where that really happens is in the mid-40s with bebop and the breakup of the big bands. Women were present, of course as singers. Now you have the shift away from dancing, which takes two, usually one male and one female. So women were included in that pre-war jazz world, and then it becomes something different. David Ake wrote a chapter-actually it was published in American Music-on Ornette Coleman, who struggled over gender identity, which is something I wasn't aware of. He very much resisted the kind of jazz which was just about phallic display and competition and everything. He really resented it when women came up on the bandstand afterwards to pick up the musicians-this whole dynamic of the virtuosic musician and the adoring women. He fought to figure out ways to step outside that gender system, including consulting with a doctor about the possibility of being castrated. And so Ake goes into that in a really sensitive way about the male ideal of the jazz musician as someone who plays higher and faster and louder than everyone else, and of course, has the woman of his choice after the gig. That's a very powerful and long-standing ideal for a lot of people. Ornette Coleman is this amazing counterexample of someone who sees that and is freaked out by it. Jazz has a very strange history from the point of view of gender. There's Billy Tipton, a pianist who passed as male through her career in jazz. She was even married a couple of times and "his" second wife claimed not to know that he wasn't a man. When Billy died ten years ago or so, there was this story in the Village Voice about it, this amazing pressure to live a life that way so as to be able to live in that completely male world of jazz history.

SW: Are there points of commonality between heavy metal and jazz which have made the two seemingly disparate areas central to your work?

RW: It's always surprised me. I'm the only scholar I can think of who has written books on both jazz and rock. Those tend to be completely separate academic specializations. It really came out of the playing that I did which was so eclectic: playing in symphony orchestras, polka gigs, and jazz gigs. It was really the polka band. I learned a lot playing in the polka band, because in that world-rural Minnesota, lots of third generation Polish immigrants, German, Czechoslovakian, Slovenian-a lot of people play more than one instrument. It's not a big deal. But it's so alien to the way we teach music in the schools. I came up playing trumpet and so I think, "OK, trumpet is my instrument." And in the polka band we had a set of polkas, a set of waltzes, and a set of what was called "modern" which could be anything from country to 50s rock, and there wasn't much for the trumpet to do on those tunes. I would just stand there. So I bought myself a guitar and taught myself one chord that I could go up and 
down the neck with, and I was playing on-stage within a week. And that goes completely away from the idea-especially for piano-that you practice for thousands of hours and then after many, many years you give a recital. That's the first time you've ever performed and you're petrified. It's this idea that you get up there and you do it, and you learn by doing it. So that's how I started to play guitar, eventually getting into bands where that was all I played, or almost all I played.

TM: So the move from metal to jazz has everything to do with your experience and identity as a player.

RW: Yes, because while I was doing the classical stuff, I was also playing in the polka band, and the polka band was already a very eclectic kind of thing where you're playing ethnic music, but you're also mixing in country and rock. So that gradually got more into the rock stuff. I eventually ended up in bands that were doing more hard rock and metal, and played in a wedding band for all of the 80s. That band had the same personnel which is very rare. Nine years with the same guys. We did a lot of weddings where we would start off with jazz and then go into the rock 'n' roll stuff which worked well for people. So switching gears between different kinds of music always made sense to me.

SW: Unfortunately, that kind of switching gears isn't always welcome in the academy. In many schools there is still a resistance to the idea of popular music studies, and while undergraduate surveys in the subject are becoming common, they are frequently relegated to the social science department. How do you think this affects the way popular music is taught to undergraduates?

RW: The thing that worries me is that I know a lot of places are attracted to the enrollment that such a course can bring to the department. But they're not convinced that there is any scholarly validity to it, so they will hire an adjunct person just to teach the "rock 'n' roll" course. They bring a bunch of numbers in because that [reflects well] on the department: teaching more students per faculty. That kind of thing bothers me because I'm very conscious of the fact that I have students coming into my rock course not realizing that there's going to be work involved, not realizing that it's a history course talking about American history, and how to talk about musical meaning and musical production-a lot of serious issues. But there are other departments, even on our campus, that offer big popular culture courses that are very easy and offer an automatic ' $A$ ' and so on. That undermines the type of attitude that I want to foster: that popular culture is the culture most people have and there is nothing more serious or consequential than that. That's something they need to understand.

TM: With regard to popular music studies, what do you want your students to take away with them, and how can a particular pedagogical approach enable this?

RW: For undergrads, one important thing is to get a sense of history, because they don't come in knowing [much]. In a mass-mediated culture, any sense of history can be blurred or misplaced. I want them to be able to think about the 
present as having been enabled by the past. I want them to be able to think through present-day controversies knowing something about other controversies that happened at earlier moments. They can think more productively about Marilyn Manson or Eminem if they know something about heavy metal controversies in the $80 \mathrm{~s}$ or controversies over rock ' $n$ ' roll in the 50 s or ragtime at the turn of the century, and not just see those as misunderstandings, but as controversies where values were at stake, where people were afraid that their way of thinking and doing and feeling was being pushed out of the way by something else. And they were right to be afraid, to see those controversies not just as misunderstandings. The Cleveland Rock ' $n$ ' Roll museum has this little display of TV clips, and it's all 50's stuff: denunciations of rock 'n' roll by preachers and fundamentalists and racists. They have these clips just running and running but no contextualization, and so the message is, "Oh look, people used to think rock 'n' roll was dangerous. Isn't that silly." What you lose then are the stakes: you lose the fact that that music was promoting miscegenation in a society where many people reacted very strongly against that; that it was promoting different ideals of sexuality, of sexual display, of ways of moving the body. There were really tremendously important things on the line. It wasn't just a generation gap, it was a crisis in the reproduction of social values.

SW: So much of the literature on jazz and popular music still deals with Adorno. This is maybe taking something of a contrary position, but do we even need to talk about Adorno anymore?

RW: Well, my position was that we don't really need to be obsessive about Adorno's writings on jazz. First of all, his writings on jazz aren't original in that there were a lot of other people saying the same thing, doing the same rants about jazz. I pointed out how he took the title of his "Perennial Fashion" essay from Winthrop Sargeant's book where he talks about jazz and fashion, and so on. And Adorno's account of the origins of jazz are taken from Sargeant as well. But the other reason is that Adorno didn't do his homework. He did not know jazz the way that he knew the music that was really important to him. He did not hear in jazz the things that were going on there. [At the Toronto 2000 Intersection panel on Adorno] Lydia [Goehr] argued with me saying, "Adorno loved jazz. He loved to play those tunes at the piano." It's not the same thing to know how to play Tin Pan Alley tunes at the piano as it is to know jazz-to be able to understand what Louis Armstrong was doing. These are not the same thing. To recognize a musical/technical feature such as syncopation (which he talks about) is not the same thing as understanding why that technique is being deployed. So my argument is that Adorno doesn't have a lot to teach us about jazz. [Adorno's writings] teach us a lot of other things: about Adorno, about a lot of other people who shared certain commitments that he had, certain allegiances to different kinds of music. But in Keeping Time I have lots of other people saying basically the same thing about jazz. It wasn't a special insight. However, those of us who do jazz do need to read Adorno on Bach and Schoenberg, the things he really knew. His way of reading texts and of understanding musical procedures can help us to establish some hermeneutics for jazz. So he has a lot to teach us. And he also has a lot to teach us about why we keep 
forgetting that he has a lot to teach us. He analyzed the type of forces in culture which operate to keep us from thinking in certain ways.

SW: So in ten years when I write my big book of popular music, I will still need to include a chapter on Adorno?

RW: Yes, but part of my point is that we always see him as an obstacle.

SW: Well, he's always the starting point.

RW: Right, but people spend all their time arguing with him instead of doing what he did, either using his tools, or somebody else's tools. I think we should stop arguing with him. He didn't really know what he was talking about in the specifics when he was talking about jazz.

TM: But aren't there two different things here? There's his article on regressive listening - that's one thing - and then there is using him to work towards a new hermeneutic tradition in jazz. Those seem to be two different things to me.

RW: At least two. There is also the critique of the culture industry. And here the great thing about Adorno is that he didn't let classical music off the hook. Classical music was just as caught up in the culture industry, just as much remade and neutralized in certain ways. For him, jazz is born of commodification, while classical music has commodification thrust upon it. The result is one and the same.

SW: But with Adorno, there is still that ineffable quality of classical music.

RW: He believes that there is something to be corrupted and neutralized.

TM: And unfortunately Edward Said in Musical Elaborations picked up on that thread, which was such a surprise, and agreed with Adorno that classical music was forever tainted through commodification.

SW: There is also the denial of the social aspect of music.

RW: Yes, and then he can be used to justify one's taste. Edward Said is such an amazing intellectual, and you can learn so much about so many things from him. But then you read that book, or something he wrote in The Nation when he writes musicology. He's completely a fan, an aesthete. He is not doing with music what he does with everything else. It seems like classical music is a retreat for him, a kind of refuge.

TM: Speaking of authors, is there anything you've read recently which has made an impression on you, whether it's a scholarly work or piece of non-fiction?

RW: A couple of things. [Last summer] on the beach I read Hayden White's book The Content of the Form, which wouldn't be your standard beach-reading [all laugh], but I found it absolutely riveting. It's made me think in really interesting ways about history, textualization, and interpretation. Another book which I liked was Stephen King's new book about writing, On Writing: A Memoir of the Craft. It's sort of a literary autobiography, but it also has a lot of thinking about what it means to be a writer and to write a lot of stories about ways in which he went wrong, and what he's found that works for him. It's 
actually very simple, I can tell you in a nutshell: just write 2000 words every morning. That's all you need. [all laugh] There is also a book I've just started [Advice for New Faculty Members: Nihil Nimus by Robert Boice] which is a handbook of advice for young professors. Boice has been researching this for decades and he says that there is a group of about $3 \%$ to $5 \%$ of new professors who are the real self-starters who just take-off and run right through tenure and have no problems. But the rest, which is most people, have to figure out strategies and flounder around, and so on. And that's who this book is aimed at: from having studied the others, [Boice looks at] the people who have problems and makes a couple of what seem like really simple points. One is that you have to write everyday, even if it's only for 15 minutes, which is kind of surprising. He states that you can't wait for that two-hour block. You've got to grab it when you can, because if you do that every day, the work is always in your mind. You find yourself thinking about it on the bus or elevator, so when you get back to your 15 minutes, you have something to say. Whereas, if you wait till Saturday and you've got the whole day, you still have to remember what you did the previous week and get back into the swing of things.

SW: That's when you start doing the housework.

RW: Exactly. And Stephen King emphasizes the lack of distractions. What you need is a desk and a chair, a door that closes, no phone, to which, I might add, no Internet connection. The other thing that Boice emphasizes is that young professors who are most successful are people who are able to balance things. One trap is to put all of your time into teaching, into preparation, and not have time for other things. But another trap is to think of writing as the only thing that matters, because it's not: teaching matters, departmental responsibilities matter, and having a life outside of this matters. You need to balance these things and not beat yourself up if you're not doing as much writing as you think you should, if you're doing these other things that you want to be doing.

TM: So what are you working on now? What is next for you?

RW: It's a little difficult to say right now. I've been editing the journal American Music and I've been chairing the department [at UCLA]. The department's been changing so there's a lot to do. I haven't had time off for a while so I'm going to take a quarter off next year to really get back into some writing. I did a bunch of Grove articles including the main one for North American pop music, and there have been other things like that. I think I want to stay with jazz for another book because I get discouraged about popular music studies sometimes. There seem to be so many books that are pulling us backwards, away from the music. There are [several] collections coming out of English departments, where the actual sounds are not addressed, or addressed in a really vague sort of way. I don't know how many books I have seen that are edited by three English scholars who have never published on popular music and are claiming to revolutionize the field without really ever having read anything. That's discouraging because they are flooding the market with stuff that is leading us away from the sounds. And it seems to me that the sounds are what it's all about. People don't fill arenas 
to listen to poetry readings. It's the music and the musical experience that we've got to grapple with.

\begin{abstract}
In late autumn of 2000 , thousands of music scholars gathered at an international mega-conference in Toronto. On that occasion, Teresa Magdanz and Simon Wood met privately with Robert Walser, Professor of Musicology at UCLA, to discuss a number of questions pertinent to popular music studies, many of which were raised at the conference. In their interview they explore the trajectory of his work, his thoughts on the relationship between music scholarship and performance, and his reflections on popular music and the academy, the implications of which extend beyond popular music studies to challenge the broader scope and practice of musicological scholarship.
\end{abstract}

\title{
Résumé
}

À la fin de l'automne 2000, Toronto a été l'hôte d'un congrès international d'envergure qui a rassemblé des milliers de chercheurs en musique. À cette occasion, Teresa Magdanz et Simon Wood ont tenu une séance privée avec Robert Walser, professeur de musicologie à UCLA; ils ont débattu de nombreuses questions se rapportant à l'étude des musiques populaires, dont plusieurs avaient été soulevées lors du congrès. Les interviewers explorent la trajectoire des travaux de Walser, sa pensée sur les relations qu'entretiennent le savoir musical et l'interprétation, de même que ses réflexions sur la musique populaire et l'institution, dont les implications dépassent l'étude des musiques populaires et mettent en question la portée et la pratique du savoir musicologique. 